\title{
Sex, seasonal and spatial differences in the diet of Cantabrian chamois Rupicapra pyrenaica parva
}

\author{
F. Javier PÉREZ-BARBERÍA, Mamen OLIVÁN, \\ Koldo OSORO and Carlos NORES
}

\begin{abstract}
Pérez-Barbería F. J., Oliván M., Osoro K. and Nores C. 1997. Sex, seasonal and spatial differences in the diet of Cantabrian chamois Rupicapra pyrenaica parva. Acta
\end{abstract} Theriologica 42: $37-46$.

The relationships between availability and quality of food, diet composition and habitat use of female and male chamois herds Rupicapra pyrenaica parva (Cabrera, 1911), were investigated in the Cantabrian Mountains (Spain). The two vegetation types studied were grass-forb and shrub. Grass-forb contained higher crude protein and lower fibre than shrub throughout year (crude protein: $17.2 \%$ vs $8.6 \%, p=0.018$; acid detergent fibre: $27.0 \%$ vs $35.8 \%, p=0.018$ ). The diet of female and male herds showed more grass-forb than shrub $(p=0.012)$, however, a discrepancy between site selection and bite selection was found. Generally male herds were found in shrub areas although they mainly chose grass-forb in their diet. Female herds had a higher percentage of grass-forb in the diet than male herds throughout the year $(81.6 \%$ vs $65.6 \%)$. Diet composition pattern was similar in both sexes, with a peak of grass-forb in spring and autumn, and a minimum in summer. Both sexes selected grass-forb throughout the year, but its use was increased when its quality was high, independently of quantity available. Females showed higher grazing activity than males throughout year $(53 \%$ vs $37 \%, p<0.0001)$. Male herds showed less grazing activity during the rut (October-November) in comparison with the rest of the year (25\% vs $43 \%, p<0.0001$ ). Some hypotheses to explain the segregation of the herds of both sexes are presented and discussed.

Facultad de Biología, Dpto. Biología de Organismos and Sistemas, Universidad de Oviedo, Oviedo 33071, Spain (JFP-B, CN); Instituto de Experimentación y Promoción Agraria del Principado de Asturias, Apdo. Villaviciosa 13-33300, Asturias, Spain (MO, KO)

Key words: Rupicapra pyrenaica parva, grazing ecology, diet composition, sexual segregation, Cantabrian Mountains, Spain

\section{Introduction}

The available studies on grazing activity of chamois mainly describe diet (Onderscheka 1974, Dunnat 1977, Obrtel et al. 1984, Perle and Hamr 1985, Kozená 1986, Onderscheka et al. 1986), only a few show the relationships between diet and vegetation availability (Ferrari and Rossi 1985). As comparisons between different studies have been limited to available vegetation and habitat conditions, general conclusions regarding chamois diet selection are difficult to draw. 
The aggregation pattern of chamois can be defined by three group structures: (1) female herds accompanied by kids or yearlings, and non-breeding females or females which have lost their kids, (2) male herds, and (3) solitary males. This pattern has been described in several chamois populations (Krämer 1969, Schröder 1971, Shank 1985). These groups can be spatially or temporally segregated occupying the same spatial areas (Shank 1985, Pérez-Barbería and Nores 1994). An explanation of this pattern of male behaviour (Shank 1985) is that it is due to food demand and the necessity of isolation, although these explanations are not consistent.

In this study the following aims were explored in two kinds of aggregations, female herds and male herds of Cantabrian chamois Rupicapra pyrenaica parva (Cabrera, 1911) in the Cantabrian Mountains (Spain), (1) diet composition and grazing behaviour throughout the year, in relation to availability and food quality, (2) relationship between habitat use and diet in both sexes.

\section{Materials and methods}

\section{Study area}

The study area was located in a $12.2 \mathrm{~km}^{2}$ valley in the Game Reserve of Reres (Cantabrian Mountains, north of Spain). Altitude ranges from 700-1709 m. A large portion of the study area was composed of siliceous soils which were vegetated with heaths (30\%) (Erica australis, E. arborea and Calluna vulgaris). The shrub Genista hispanica and Genista legionensis (14\%) and subalpine meadows (9\%) dominated calcareous soils. The dominant tree species were Fagus sylvaticus (28\%) and Betula pubescens (2\%). For more details about vegetation cover see Pérez-Barbería (1994) and Pérez-Barbería and Nores (1994). Between 1991 and 1992 the chamois population in the area was estimated at 170 individuals. Hunting activity was low between 1991 and 1994, being less than 6\% of the estimated population.

\section{Sampling faeces to estimate diet composition}

Between April and December 1994, faeces of adult chamois herds of both sexes were collected (23 females, 32 males and 10 unknown sex faeces). A herd was considered as the aggregation of chamois where no adult individual was more than $50 \mathrm{~m}$ from any other animal in the same group (Clutton-Brock et al. 1982). Individual animal were excluded in this study. Adults were considered those animals more than 1 year old, their faeces can be differentiated by size from those of younger animals. To ensure that the faeces were known to be from a male or female, the herds were observed and the sex and approximate age of all individuals was determined (Pérez-Barbería et al. 1996). Animals were observed defecating and the place, date and animal sex noted. After collection in the field, the faeces were kept cold, no longer than 2 days, until they could be stored at $-20^{\circ} \mathrm{C}$. The faeces were then freeze dried, milled and vacuum packed until analysis.

\section{Diet composition}

We estimated chamois diet composition by determining the concentration of n-alkanes in the faeces and in the vegetation eaten by chamois, using the method of Oliván and Osoro (1994) n-alkanes technique (which is a modification of Mayes et al. 1986 and Dove and Mayes 1991). The n-alkanes were extracted in heptane, and quantified employing gas chromatography and using two internal standards added previously to the sample, $\mathrm{C}_{22}$ and $\mathrm{C}_{34}$. We corrected the faecal concentration of n-alkanes in relation to their recovery rate in faeces, because in ruminants the recovery of alkanes is not complete 
and varies in relation to the length of hydrocarbon chain (Dove and Mayes 1991). Since the faecal recovery of alkanes was not known for chamois, the recovery of faecal alkanes from sheep grazing in mountain meadows (M. Oliván, unpubl.) was used. The vegetation categories considered in chamois diet were, grass-forb and shrub (heath and Genista). Since both categories are not independent in relation to total diet, grass-forb and shrub exhibit inverse patterns of abundance in the diet.

\section{Pasture height}

The pasture height was taken in six unfenced independent plots (between 105 and $500 \mathrm{~m}^{2}$ ). Three of these plots were placed within altitude ranges of $1540-1640 \mathrm{~m}$, and they were located in areas not used by livestock due to difficult access (very steep slopes and cliffs). The other plots were placed between 1450 and $1500 \mathrm{~m}$, and their pasture height dynamics were conditioned to livestock grazing (mainly cattle and horses). The height of the pasture was measured with a graduated stick $( \pm 5 \mathrm{~mm})$ using between 36 and 170 randomly distributed points per plot. During this study the snow reduced the uncovered surface of some of the plots, but it did not impede the measurements. Height of grass-forb was considered an estimator of available pasture and grazing pressure (Illius 1986). The seasonal changes of Genista hispanica, G. legionensis, and heather height were not measured.

\section{Pasture nutrient content}

To estimate the pastures nutrient content, different plants which were used by chamois were collected monthly. We determined the plants and their parts grazed by chamois using direct observation of the grazing behaviour. With this method it was not possible to identify a large proportion of the plant species eaten. Consequently the following vegetation groups and species were collected: grass-forb from subalpine meadows, Erica cinerea, E. vulgaris, E. vagans, E. arborea, E. australis, Genista hispanica, and $G$. legionensis. Plant collections were made along a transect, clipping shrubs and meadows. Plants were kept in a cool place for no longer than 2 days, until stored at $-20^{\circ} \mathrm{C}$ in the laboratory. They were freeze dried and milled, and vacuum packed until analysis.

The following nutrient contents were analysed: protein (CP), percentage of crude protein in dried matter (Kjeldahl nitrogen $\times 6.25$ ), using Kjeltec-Auto Tecator equipment, and percentage of acid detergent fibre (ADF) using Van Soest and Wine (1968) method. In a preliminary analysis the nutrient contents of different shrub species was very similar, therefore to facilitate the interpretation of alkane data, all shrubs were pooled in the alkane analyses. As a result the two vegetation groups considered were (1) grass-forb and (2) shrubs.

\section{Grazing activity}

As the same time as the faeces and pasture collections, chamois diurnal grazing activity over two days was observed, using scan-sampling (Martin and Bateson 1993). This was repeated each 2 weeks. The grazing activity of all animals observed at the end of 15 minute periods was recorded. "Feeding" was considered when the animal was eating or its head was placed below their shoulder towards the ground. The percentage of feeding animals at the end of 15 minutes was considered as one sample.

\section{Habitat use}

The use of the two habitats studied (subalpine meadows and shrubs) by female and male herds, was estimated using surveys along an transect whose visual exposure was $40 \%$ of the actual study area (excluding forested areas). Records obtained in the forest were excluded, due to the low detectability of chamois in this habitat (Pérez-Barbería and Nores 1994). Between 2 and 4 surveys were conducted monthly, recording sex, age class and location of the herds on aerial photographs (scale 1:4500). Also the number of livestock grazing in the area was recorded. The analysis of this information was facilitated using the ARC/info geographic information system (Anonymous 1992). 
Since some surveys were interrupted or modified by unfavourable weather conditions, the surveyed area varied. Therefore, the availability of each vegetable community was estimated for each survey and, later, weighted for each season. Although depth and hardness of snow conditioned the use of the vegetation type that it covered (Takatsuki 1992), we considered that all snow patches impeded the use of vegetation which they covered.

\section{Statistical analysis}

Habitat preferences were determined using $\chi^{2}$ goodness-of-fit test and Bonferroni confidence intervals (Byers et al. 1984). We used the $\chi^{2}$-test to determine whether there was a significant difference between the expected utilisation of vegetation types and the observed frequency. The expected number of observations in each vegetation type was calculated by multiplying the relative area of the type by the total number of chamois sights. Bonferroni confidence intervals were used to determine which vegetation types were being preferred (Byers et al. 1984). Non-parametric statistic tests were used when the data sets, despite transformations, did not met the assumptions for the application of parametric analysis.

Pasture height throughout the year and between plots from different altitude ranges, were compared with Kruskal-Wallis and Wilcoxon matched-pairs signed-ranks tests; the latter was also used to compare the grass-forb and shrub quality throughout year. A two factor ANOVA (sex $\times$ months) was used to compare diet nutrient-contents. Grazing activity differences between the sexes and between months was analysed using Mann-Whitney $U$ and Kruskal-Wallis test respectively. Student-Newman-Keuls (SNK) parametric multiple comparisons test for parametric data, and SNK non-parametric (both $\alpha=0.05$ ) were used (Zar 1984). SPSS/PC+ statistical package was used for data analysis (Norusis 1990).

\section{Results}

\section{Pasture availability}

Pasture height in subalpine meadows showed a peak in July $(18.1 \mathrm{~cm})$, even though half of the usual livestock (40 cows, Fig. 1a) were grazing these areas. This maximum decreased quickly in August $(11.6 \mathrm{~cm})$ when the number of cows and horses was at its greatest $(n=75)$. This pattern was the same in the plots of the two altitude ranges $\left(r_{\mathrm{S}}=1.0, p=0.0, n=7\right.$; Fig 1a). Throughout the year pasture height showed significant differences among all months $\left(\chi^{2}=931.87\right.$, $p<0.0001, \chi^{2}=931.87, p<0.0001$, low and high latitude ranges respectively), except between May-December in high altitude plots $(3.8 \mathrm{~cm}$ and $3.5 \mathrm{~cm})$ and April-November $(1.5 \mathrm{~cm}$ and $1.5 \mathrm{~cm})$ and August-October $(2.6 \mathrm{~cm}$ and $2.6 \mathrm{~cm})$ in low altitude plots. All high altitude range plots showed taller pasture than low altitude range plots, throughout the year $(Z=-2.37, p=0.018$; Fig. 1a).

\section{Pasture nutrient content}

Table 1 shows nutrients content analyses of both vegetation types studied throughout the year. Both vegetation types showed an increase in crude protein $(\mathrm{CP})$ in spring, a decrease in summer, with another increase in autumn; the lowest value was in winter. ADF showed the inverse pattern. Grass-forb had higher values of $\mathrm{CP}$ and lower $\mathrm{ADF}$ than shrubs throughout the year $(Z=-2.37, p=0.018$; Fig. 1b). 
Fig. 1. (a) Pasture height in subalpine meadows in consecutive months (Cantabrian Mts, Spain). Solid line: meadows between $1540-1640 \mathrm{~m}$ altitude. Dotted line: meadows between 1450-1500 $\mathrm{m}$, and triangles: number of domestic animals. Vertical lines are \pm 1 SD. (b) Percentage of crude protein in grass-forb (white bars) and shrub (black bars).
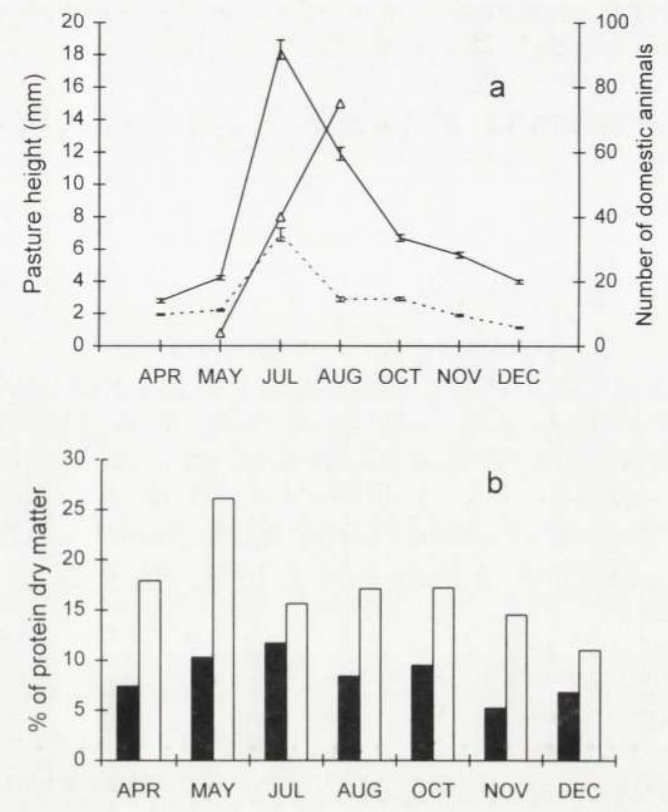

Table 1. Percentage of nutrient content of two vegetation types, shrub (mean \pm SD) and grass-forb (mean) in Cantabrian Mts, Spain in consecutive months. CP - crude protein, ADF - acid detergent fibre. $n$-number of samples of shrub. For shrub, SD is reported when sample size is $>2$.

\begin{tabular}{llccccccc}
\hline $\begin{array}{l}\text { Nutrient } \\
\text { content }\end{array}$ & $\begin{array}{l}\text { Vegetation } \\
\text { type }\end{array}$ & $\begin{array}{c}\text { April } \\
n=3\end{array}$ & $\begin{array}{c}\text { May } \\
n=5\end{array}$ & $\begin{array}{c}\text { July } \\
n=4\end{array}$ & $\begin{array}{c}\text { August } \\
n=3\end{array}$ & $\begin{array}{c}\text { October } \\
n=2\end{array}$ & $\begin{array}{c}\text { November } \\
n=2\end{array}$ & $\begin{array}{c}\text { December } \\
n=3\end{array}$ \\
\hline $\mathrm{CP}$ & Shrub & $7.6 \pm 2.0$ & $10.4 \pm 4.5$ & $11.9 \pm 3.9$ & $8.7 \pm 1.4$ & 9.6 & 5.3 & $6.9 \pm 1.7$ \\
& Grass & 17.9 & 26.2 & 15.8 & 17.3 & 17.4 & 14.6 & 11.2 \\
$\mathrm{ADF}$ & Shrub & $35.5 \pm 1.5$ & $29.3 \pm 4.9$ & $29.6 \pm 5.7$ & $35.7 \pm 1.1$ & 29.9 & 40.5 & $50.4 \pm 15.9$ \\
& Grass & 28.2 & 17.8 & 28.0 & 28.5 & 22.7 & 27.7 & 36.4 \\
\hline
\end{tabular}

\section{Diet composition}

Percentage of grass-forb and shrub in diet is shown in Fig. 2. Female herds exhibited a higher percentage of grass-forb in the diet than male herds throughout year, except in October. Diet composition pattern was similar in both sexes, with a peak of grass-forb in spring (90\% in females, $85 \%$ in males) and autumn $(85 \%$ in females, $80 \%$ in males), and a minimum in summer (55\% in females in August, $35 \%$ in males in July and August). The value of December (65\%) was pooled for both sexes, because faeces could not be attributed to either sex. Conversely, shrub percentage showed the inverse pattern. Significant differences were detected between both sexes $\left(F_{1,40}=6.88, p=0.012\right)$, months $\left(F_{4,40}=16.19, p<0.001\right)$, and also interaction between both factors $\left(F_{4,40}=2.90, p=0.034\right)$. For both sexes, 


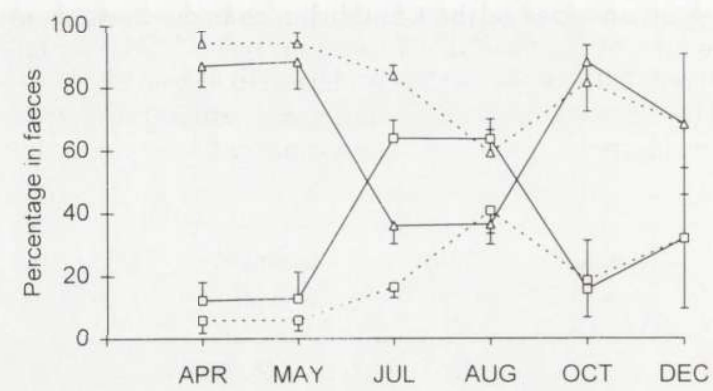

Fig. 2. Percentage of grass-forb and shrub in the chamois diet. Solid lines: males, dotted lines: females, triangle symbols: grass-forb, square symbols: shrub. Vertical lines are $\pm 1 \mathrm{SD}$.

April and May formed a group well defined, showing low shrub percentages in diet in relation to the other months. The largest differences between sexes were obtained in July and August (Fig. 2).

\section{Grazing activity}

Females showed more feeding activity than males throughout the year $(U=$ 19279.5, $p<0.0001)$. Grazing patterns exhibited different trends in both sexes throughout the year (Fig. 3). Male herds showed less feeding activity in October and November, compared with April, May, July and August $\left(\chi^{2}=34.5\right.$, df $=6$, $p<0.0001)$. Female feeding activity also varied throughout year $\left(\chi^{2}=51.72, \mathrm{df}=5\right.$, $p<0.0001$ ), the lowest values being recorded in May and October and the highest in April, August, November and December. However, April values were the highest compared with August and November, and similar to the December values.

\section{Habitat use}

Habitat use of both sexes presented a well defined pattern throughout the year. Between August and November herds of both sexes used grass meadows more

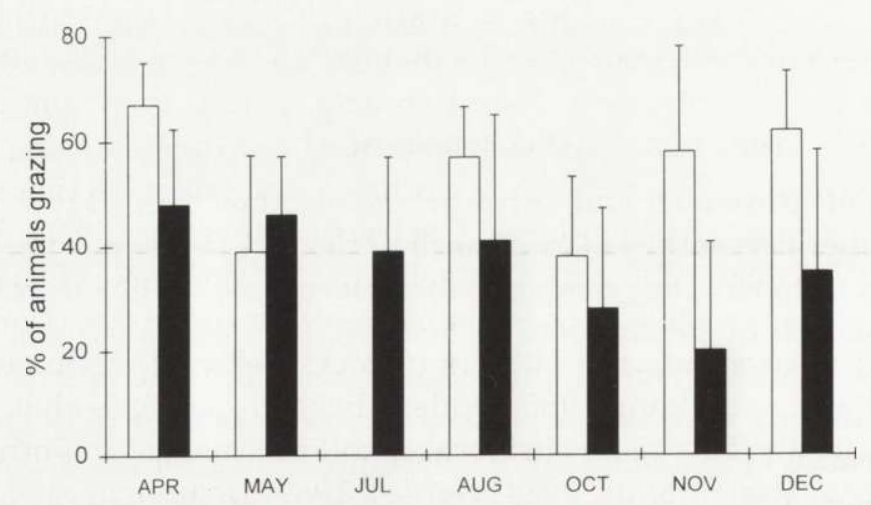

Fig. 3. Grazing activity of males and female herds. White bars: females, black bars: males. Vertical lines are $1 \mathrm{SD}$. 
Table 2. Utilisation-availability data for two vegetation types in the Cantabrian chamois throughout the year (Cantabrian Mts, Spain). AV - relative area of the available vegetation type, USE - actual proportion of usage shown in ranges. "+" - preferred (0.01-0.05), "++" - preferred (0.051-0.14), "+++" - preferred (0.14-0.50), “-" - avoided (0.01-0.05). F - females, M - males, $n$ - number of herds. Habitat preferences were determined using $\chi^{2}$ goodness-of-fit test and Bonferroni confidence intervals $99.5 \%$ (Byers et al. 1984).

\begin{tabular}{|c|c|c|c|c|c|c|c|c|c|c|c|c|c|c|c|c|}
\hline & \multicolumn{2}{|c|}{$\begin{array}{c}\text { April } \\
n=102\end{array}$} & \multicolumn{3}{|c|}{$\begin{array}{c}\text { May } \\
n=158\end{array}$} & \multicolumn{3}{|c|}{$\begin{array}{c}\text { July } \\
n=43\end{array}$} & \multicolumn{2}{|c|}{$\begin{array}{c}\text { August } \\
n=90\end{array}$} & \multicolumn{2}{|c|}{$\begin{array}{l}\text { October } \\
n=271\end{array}$} & $\begin{array}{c}\text { November } \\
n=80\end{array}$ & \multicolumn{3}{|c|}{$\begin{array}{c}\text { December } \\
n=42\end{array}$} \\
\hline & AV & USE & AV & & $\mathrm{SE}$ & AV & US & SE & AV & USE & AV & USE & AV USE & AV & US & \\
\hline & & $\mathrm{F} \mathrm{M}$ & & $\mathrm{F}$ & M & & $\mathrm{F}$ & M & & F $\mathrm{M}$ & & $\mathrm{F} \mathrm{M}$ & F $\mathrm{M}$ & & $\mathrm{F}$ & M \\
\hline Grass & 0.57 & & 0.57 & +++ & - & 0.57 & & & 0.57 & + & 0.57 & ++++ & $0.57++$ & 0.60 & & \\
\hline Shrub & 0.27 & + & 0.27 & - & +++ & 0.27 & +++ & +++ & 0.27 & & & $-\quad-$ & 0.27 & 0.24 & +++ & +++ \\
\hline
\end{tabular}

than would be expected at random. Shrub was never preferred and female herds avoided its use in October (Table 2). On the other hand, between December and July, shrub was used more than it would be expected by chance, primarily by males. Female herds only selected it less than it would be expected by chance in May (Table 2).

\section{Discussion}

Generally in the diet of female and male herds grass-forb was prefered to shrub, especially during spring (April, May) and autumn (October, December). However significant differences were found between sexes. Although the diet of male herds during the months of April, May and December constituted grass-forb, males were chiefly found in shrub areas. This discrepancy between diet selected and habitat used can be explained considering diet is the result of several factors interacting, preference for some plants, habitat limitation and external disturbances (Hodgson 1982). Therefore diet selection may be divided into two factors, site selection and bite selection (Milne 1991). Site selection acts within a horizontal plane to very different scales, from meters to kilometres, the animal moving and searching determining grazing efficiency. On the other hand, bite selection acts directly on plants or parts plant within the site selected (Hodgson 1982). We have found discrepancies between site and bite selection in the case of male herds. This discrepancy was suggested in chamois by Pérez-Barbería and Nores (1994). This corroborates the observations of others (Onderscheka 1974, Dunant 1977, Obrtel et al. 1984, Perle and Hamr 1985, Onderscheka et al. 1986) that chamois prefer grass-forb to shrub. This diet considerably differs from that of other species such as domestic goat (Grant et al. 1984, Gordon 1989, Domingue et al. 1990, Cuartas and García-González 1992) and wild goat (Cuartas and García-González 1992) in which woody plants predominate. 
The relationships between crude protein and grass-forb in the diet, suggest that both sexes increased the use of grass-forb when its content of crude protein was high (April-May). So the best quality of grass-forb in the diet was available in April and May, when crude protein values were the highest and ADF values were the lowest of the year, although grass-forb quantity available was less than July and August. In summer and the early winter the percentage of shrub in the diet increases when the quantity and quality of the grass-forb decreased. Similar patterns have been described by other authors when the use of woody species was compared with grasses and forbs (Obrtel et al. 1984, Perle and Hamr 1985, Grant et al. 1987). On the other hand the surveys showed that chamois did not graze close to livestock; indirectly, livestock may influence chamois grazing behaviour.

Male herds used shrub communities more frequently and also the diet contained more shrub than females throughout the year. This behaviour has also been observed in red deer (Clutton-Brock et al. 1982, Staines et al. 1982). We do not know what produces this spatial segregation in the herds of each sex, but this segregation can reduce feeding competition, and presumably benefits the females, compensating the costs of breeding and lactation. Lone males, which exhibit habitat overlap with female herds, should obtain the same benefits that female herds, in relation to male herds. An hypothesis to explain the sexual segregation of the herds may be competition between males. Dominant males fight for the best quality pastures areas. Sub-dominant males are excluded from these areas and they would constitute herds. On the other hand, dominant male establishes a territory, but it would be tolerant to females and calves. This energetic cost to maintain a territory would revert on themselves in relation to pasture quality and during the rut season with easier access to females. This is consistent with some observations (F. J. Pérez-Barbería, pers. comm.) on marked dominant males, which remained in the same areas throughout the year; these areas were usually the same ones used during the rut. On the other hand, if the increase of the body size in herbivorous involves increase in the efficiency at ruminating (Parra 1978, Demment 1982, Gross et al. 1995), chamois females would be less efficient at ruminating than males. They might compensate this with a richer diet than the dominant male areas offer them. However, more information is necessary to test this hypothesis.

Males exhibited the lowest grazing activity in October and November, coinciding with the rut. In November the grazing activity of males was only $20 \%$, half that recorded throughout most of the year and 3-fold less than in December. In December the wide variation of the male grazing activity data set can probably be attributed to some males still being in rut. Females seemed to optimise their grazing activity in relation to available food, more efficiently than males. The peaks of grazing activity were recorded in December and April, when quality and food availability were at their lowest. In August the time spent in grazing by both sexes was longer than expected in relation to grass-forb availability. But this may be due to a decrease in crude protein content, increase in $\mathrm{ADF}$ and greater numbers 
of livestock. In conclusion, the variation obtained in grazing activity of chamois was basically determined by several factors, quality and available food throughout year, physiological activity and interaction with other animal species.

Acknowledgements: We are indebted to G. Mutuberría and J. Ruiz for their assistance in the field and laboratory work. O. Hernández assisted in several aspects of this study. G. Iason performed a critical reading of the manuscript. M. Taylor reviewed the English. This research was supported by CICYT (Comisión Interministerial de Ciencia y Tecnología Project no. 91-0911-FOR-217) and Consejería de Medio Ambiente y Urbanismo del Principado de Asturias (Grant 04-060-91). For the duration of this study the senior author held a grant from FICYT (Fundación para el Fomento en Asturias de la Investigación Científica y Tecnologíca). The reviews of this paper were carried out by the senior author at The Macaulay Land Use Research Institute, supported by funding from Programa de Becas de Formación de Personal Investigador en el Extranjero (Ministerio de Educación y Ciencia, Spain) and European Community.

\section{References}

Anonymous. 1992. Understanding GIS. The ARC/INFO Method, Rev. 6. Environmental System Research Institute Inc. Redlands, California, USA.

Byers C. R., Steinhorst R. K. and Krausman P. R. 1984. Clarification of a technique for analysis of utilization-availability data. Journal of Wildlife Management 48: 1050-1053.

Clutton-Brock T. H., Guinness F. E. and Albon S. D. 1982. Red deer. Behaviour and ecology of two sexes. University of Chicago Press, Chicago: 1-378.

Cuartas P. and García-González R. 1992. Quercus ilex browse utilization by Caprini in Sierra de Cazorla and Segura (Spain). Vegetatio 99/100: 317-330.

Demment M. W. 1982. The scaling of ruminoreticulum size with body weight in East African ungulates. African Journal of Ecology 20: 43-47.

Domingue B. M. F., Dellow D. W., Wilson P. R. and Barry T. N. 1990. Comparative nutrition of deer and goats, goats and sheep. Proceedings of the New Zealand Society of Animal Production 50: $39-42$.

Dove H. and Mayes R. W. 1991. The use of plant wax alkanes as markers substances in studies of the nutrition of herbivores: a review. Australian Journal of Agricultural Research 42: 913-957.

Dunant F. 1977. Le régime alimentaire du chamois des Alpes (Rupicapra rupicapra rupicapra L.): contribution personnelle et synthèse des données actuelles sur les plantes broutées. Revue Suisse de Zoologie 84: 883-903.

Ferrari C. and Rossi. 1985. Preliminary observations on the summer diet of the Abruzzo chamois (Rupicapra rupicapra ornata Neum.). [In: The biology and management of mountain ungulates. S. Lovari, ed]. Croom-Helm, London: 85-92.

Gordon I. J. 1989. Vegetation community selection by ungulated on the isle of Rhum. III. Determinants of vegetation community selection. Journal of Applied Ecology 26: 65-79.

Grant S. A., Bolton G. R. and Russel A. J. F. 1984. The utilization of sown and indigenous plant species by sheep and goats grazing hill pastures. Grass and Forage Science 39: 361-370.

Grant S. A., Torvell L., Smith H. K., Suckling D. E., Forbes T. D. A. and Hodgson J. 1987. Comparative studies of diet selection by sheep and cattle: blanket bog and heather moor. Journal of Ecology 75: 947-960.

Gross J. E., Demment M. W., Alkon P. U. and Kotzman M. 1995. Feeding and chewing behaviours of Nubian ibex: compensation for sex-related differences in body size. Functional Ecology 9: 385-393.

Hodgson J. 1982. Influence of sward characteristics on diet selection and herbage intake by the grazing animal. [In: Nutritional limits to animal production from pastures. J. B. Hacker, ed]. CAB. Proceeding International Symposium, St. Lucia, Queensland, Australia: 153-166. 
Illius A. W. 1986. Foraging behaviour and diet selection. [In: Grazing research at northern latitudes. O. Gudmunson, ed]. NATO 108: 227-236.

Kozená I. 1986. Further data on the winter diet of the chamois, Rupicapra rupicapra rupicapra, in the Jeseníky Mountains. Folia Zoologica 35: 207-214

Krämer A. 1969. Soziale Organisation und Sozialverhalten einer Gamspopulation (Rupicapra rupicapra L.) der Alpen. Zeitschrift für Tierpsychologie 26: 889-964.

Martin P. and Bateson P. 1993. Measuring behaviour. An introductory guide. (2nd edn). Cambridge University Press, Cambridge: 1-222.

Mayes R. W., Lamb C. S. and Colgrove P. M. 1986. The use of dosed and herbage n-alkanes as markers for the determination of herbage intake. Journal of Agricultural Science, Cambridge 107: 161-170.

Milne J. A. 1991. Diet selection by grazing animals. Proceeding of the Nutrition Society 50: 77-85.

Norusis M. 1990. SPSS/PC+ 4.0. Base manual for the IBM PC/XT/AT and PS/2. Chicago.

Obrtel R., Holisová V. and Kozená I. 1984. The winter diet of chamois, Rupicapra rupicapra rupicapra, in the Jeseníky Mts. Folia Zoologica 33: 327-338.

Oliván M. and Osoro K. 1994. Posibilidades de la técnica de los n-alcanos en la estimación de la ingestión, digestibilidad and composición de la dieta de rumiantes en pastoreo. XXXIV Reunión Científica de la Sociedad Espan̄ola para el Estudio de Pastos, Mayo, Santander, Spain: 391-396.

Onderscheka K. 1974. Ernährungsprobleme bein Gamswild. Tagungs Bericht der 1. Internazionale Gamswildtreffen, Oberammergau: 34-52.

Onderscheka K., Kutzer E. and Richter H. E. 1986. Die Räude Gemse und ihre Bekämpfung. II Zusammenhänge zwischen Erhährung und Räude. Zeitschrift für Jagdwissenschaft 14: 12-27.

Parra R. 1978. Comparison of foregut and hindgut fermentation in herbivores. [In: The ecology of arboreal folivores. G. G. Montgomery, ed]. Smithsonian Institution Press, Washington, D.C.: 209-229

Pérez-Barbería F. J. 1994. Biología, ecología y caracterización genética del Rebeco cantábrico (Rupicapra pyrenaica parva). $\mathrm{Ph} \mathrm{D}$ thesis, Oviedo University, Spain: 1-112.

Pérez-Barbería F. J. and Nores C. 1994. Seasonal variation in group size of Cantabrian chamois in relation to escape terrain and food. Acta Theriologica 39: 295-305.

Pérez-Barbería F. J., Robles L. and Nores C. 1996. Horn growth pattern in Cantabrian chamois (Rupicapra pyrenaica parva): Influence of sex, location and phaenology. Acta Theriologica 41: $83-92$.

Perle A. and Hamr J. 1985. Food habits of chamois (Rupicapra rupicapra L.) in northern Tyrol. [In: The biology and management of mountain ungulates. S. Lovari, ed]. Croom-Helm, London: 77-84.

Schröder W. 1971. Untersuchungen zur Ökologie des Gamswildes (Rupicapra rupicapra L.) in einem Vorkommen der Alpen. Teil I u. II. Zeitschrift für Jagdwissenschaft 17: 113-168, 197-235.

Shank C. C. 1985. Inter- and intra-sexual segregation of chamois (Rupicapra rupicapra) by altitude and habitat during summer. Zeitschrift für Säugetierkunde 50: 117-125.

Staines B. W., Crisp J. M. and Parish T. 1982. Differences in the quality of food eaten by red deer (Cervus elaphus) stags and hinds in winter. Journal of Applied Ecolology 19: 65-77.

Takatsuki S. 1992. Food morphology and distribution of Sika deer in relation to snow depth in Japan. Ecological Research 7: 19-23.

Van Soest P. J. and Wine R. H. 1968. Determination of lignin and cellulose in acid detergen fiber with permanganate. Journal of the Association of Official Agricultural Chemists 51: 780-785

Zar J. H. 1984. Biostatistical analysis. (2nd edn). Prentice-Hall, New Jersey: 1-718.

Received 12 February 1996, accepted 2 November 1996. 